\title{
Fire history and climate-growth response of Abies spectabilis : A case from Langtang National Park, Nepal Himalaya
}

\author{
S. Basnet ${ }^{1,4^{*}}$, N. P. Gaire ${ }^{2}$ and P. K. Chhetri ${ }^{3}$
}

This study presents the potential of a conifer species (Abies spectabilis D. Don) to reconstruct fire history by using dendrochronological technique along with the dendroclimatic response in Langtang National Park, Central Himalaya of Nepal. For the fire history reconstruction, altogether eight cross-sections samples from fireaffected eight trees and another 20 tree-cores from 10 trees with visible fire scars were taken. In the case of dendroclimatic study, 24 healthy cores of $A$. spectabilis were selected from the 40 cores extracted from 19 trees. The standard dendrochronological methodology was used for sample preparation and analysis. A 199-year long ring-width chronology of $A$. spectabilis spanning from 1818 to 2016 AD was developed. In spite of visible fire burn in near bark-surface, no potential fire scars are seen in inner parts in the cross-section samples. However, 12 cores showed that three fire burns occurred simultaneously in the forest area in the years 1917-1918, 1969-1970 and 2009-2010, respectively. Tree-ring-based fire event-record is found to be concurrent to the local people's perceptions/experience about the past fire history in the area. Tree growth climate relationship showed sensitive responses to both growing and non-growing season's temperature and precipitation variability. Summer temperature had positive influence on growth of the species. Precipitation of monsoon and autumn were found to have negative influence on radial growth whereas pre-monsoon precipitation had positive association with tree radial-growth. This preliminary assessment shows that there is a huge potential of tree-ring research for long-term fire history in the region and helps us to better understand the role of fire in the ecology and management in the Himalayan region. The study can also be replicated in other fire-affected areas of the Himalayan region by using fire sensitive species in the sampling.

Keywords : Abies spectabilis, climate, dendrochronology, fire scar, tree growth, tree rings

$\mathrm{F}$

ire is an integral component of the earth system, and plays a key role in regulating vegetation structure and ecosystem function (Pausas and Keeley, 2009). It is also recognized as an important ecosystem process globally (Hurteau et al., 2014), and is both human-induced and natural one (Fowler and Konopik, 2007; Cohen et al., 2007). Fire regime is relatively influenced by multiple factors, and understanding them is one of the fundamental objectives of fire ecology, and this knowledge is critical for improving our ability to forestall

future fire regime changes. A series of factors are thought to influence fire activity such as climatic variability like temperature and precipitation (Bradstock, 2010). For example, when it is dry in a year after relatively wet years, forest fire is inclined to occur. Fire history is also related to large-scale climatic events. For instance, fire always occurs in the years of transition from El Niño to La Niña (Xiaochun and Ying, 2009), and phase combination of large-scale climatic events is more likely than a single event to lead to fire. In addition, landscape-scale patterns of

\footnotetext{
Nepal Academy of Science and Technology (NAST), Khumaltar, Lalitpur, Nepal

Key Lab of Tropical Forest Ecology, Xishuangbanna Tropical Botanical Garden, Chinese Academy of Sciences, Menglun, Mengla, 666303, Yunnan, PR China

3 Department of Earth Science and Geography, CSU Dominguez Hills, USA

4 Golden Gate International College, Battisputali, Kathmandu, Nepal * Correspondence: basnetsaroj1992@gmail.com
} 
vegetation (Heon et al., 2014), topography and land use change (Rollins et al., 2002; Moreira et al., 2011), human activities (Liu et al., 2012; Pausas and Fernández-Muñoz, 2012) are also the crucial one. Besides, factors such as fuel characteristics, fire management activities and climate change are also considered to influence fire activity in a region (Dimitrakopoulos et al., 2011a). An attempt on tree-ring based fire study have been done in Himalayan region of India (Brown et al, 2011) and Bhutan (Gyeltshen and Tenzin, 2018), but no studies have been carried out in the Himalayan region.

In Nepal, human-induced forest fire is considered as one of the main reasons for alterations in forest ecosystems and loss of biodiversity in all the major physiographic/climatic regions including the Terai and Bhabar, the Siwaliks or the Inner Terai, the Middle Mountains, and the High Mountains regions (GoN/MFSC, 2010). Mostly forest fires occur during the dry season from February to June; and once the monsoon starts, fire problem disappears (Sharma, 1996). However, wide range of challenges related to institutional, policy and legal frameworks have been identified as lacking (GoN/MFSC, 2010). Not only that, lack of sufficient fire statistics for Nepal has also been recognized as one of the major problems for studying fire ecology in Nepal.

Dendrochronology is an interdisciplinary science with wider applications in multiple sectors including forestry and climatology (Speer, 2010). So, inspecting fire-scarred trees dated with dendrochronological techniques will be reliable method for providing quantitative information on fire-regime evidence at multiple scales to study fire events, their frequency, severity and patterns even on remote geographical area. Though several tree-ring related studies have been carried out in Nepal (Cook et al., 2003; Chhetri and Thapa, 2010; Gaire et al., 2011, 2014, 2016) but study regarding the fire disturbances in the perspective of dendroecology is still lacking in the whole country (Gaire et al., 2013; Thapa et al., 2017). So this study will help to inform management, and provide insight into the effects of fire on study area. Similarly, it helps to fill the research gap in dendroecology and fire impacts in mountain forest dynamics. Further, it forms the baseline for future studies along with the influence of climate on its radial growth.

\section{Materials and methods Study area}

The study site was carried out in Cholangpati, Laurabinayak, Chandanbari and Deurali area lying within the Langtang National Park (LNP, Figure 1). Extending over an area of $1,710 \mathrm{~km}^{2}$, it was established in 1976, and is the fourth protected area in Nepal. It is the first Himalayan national park, and is surrounded by a buffer zone of $420 \mathrm{~km}^{2}$. The National Park covers an area of $1,710 \mathrm{~km}^{2}$ encircling 26 Village Committees of Nuwakot, Rasuwa and Sindhupalchok districts of the central Himalayan region. The LNP is situated between $28^{\circ} 10^{\prime} 26^{\prime \prime} \mathrm{N}$ and $85^{\circ} 33^{\prime} 11^{\prime \prime} \mathrm{E}$. The northern and eastern borders of the LNP coincide with the international border and are linked with the Qomolangma National Nature Preserve in Tibet while the western boundary follows the Bhote Kosi and Trishuli rivers.

As LNP extends from $792 \mathrm{~m}$ to $7,245 \mathrm{~m}$ above mean sea level (the peak of Mt. Langtang Lirung), there is an extreme climatic contrast with tropical climate in the south to arctic climate in the north. The southern part is warmer with an average temperature of $30^{\circ} \mathrm{C}$ in summer and $10^{\circ} \mathrm{C}$ in winter while the northern part is very cold below freezing point. The six different climatic zones are noted in the region : tropical, subtropical, temperate, subalpine, alpine and arctic. Winter is very cold, and there is snowfall for six months (December to May). June and September are the monsoon months with three-fourth of the annual rainfall. The post-monsoon period from October to November and winter months from December to February are usually dry. The average rainfall is $1,900 \mathrm{~mm}$ per annum.

The area is composed of a mosaic of habitats, including grass land, shrub land, and few tree stands. Patches of Berberis mucrifolia and Rhododendron lepidotum comprise the major shrub species in the shrub land in the upper subalpine region $(3,600-4,000 \mathrm{~m})$ of the valley whereas few patches of Juniperus indica are also present on the valley floor at around 3700 $\mathrm{m}$ a. s. 1. The well-known shrub species such as $R$. setosum, $R$. anthopogon, Hippophae tibetana and Juniperus spp. are wide spread from about $4,000 \mathrm{~m}$ up to $4,500 \mathrm{~m}$ amsl. On the other hand, parts of the northern and northwestern facing mountain slopes of the Valley are dominated by 
tree species like Betula utilis, A. spectabilis and $R$. campanulatum. They form a forest belt in the upper subalpine zone. B. utilis, $R$. campanulatum or combinations of these tree species forms the forest line at $4000 \mathrm{~m}$ a. s. 1 .

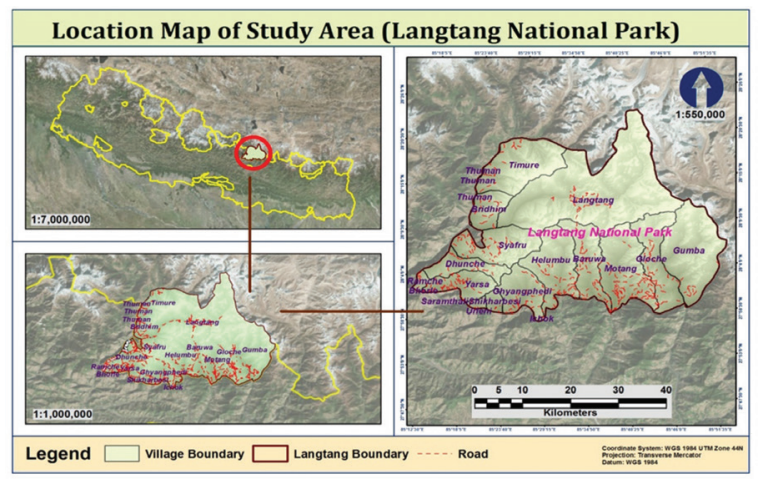

Figure1 : Location Map of the Study Area (Langtang National Park), Himalayan region

\section{Data and sample collection}

Both primary and secondary data were used in the present research. Primary data (tree cores samples and cross-sections from the fire scarred trees) were collected from the field survey. Similarly, the secondary data were acquired through different literatures, reports, journals, articles etc. Likewise, the climatic data were obtained from the nearby station of the study area. The primary data were collected in the following ways :

Non-probability sampling method developed by Beaty and Taylor (2008) was followed for the selection of both the area and trees as the study was, moreover, concentrated on fire history reconstruction. First of all, the forest stands susceptible to fire were identified and selected on the basis of the detailed literature review and the preliminary observation in the field. Both the living and dead trees with distinct cat's eye scars from fire in their trunks were taken for sampling. A systematic survey was conducted on foot, starting from one edge of the sample site to the other edge following the procedures of (Christopoulou et al., 2013). The cross-sections of the charred or blackened trunks or barks with the scars of charcoal were collected from the felled trees. The cores of the standing trees, at basal height $(30 \mathrm{~cm}$ above the ground) indicating the longest and most complete fire history based on externally visible fire scars and wood preservation, were collected with the help of the Pressler's Increment Borer
(Speer, 2010 and Skinner et al., 2008). The closely situated old trees in the site were cored to cross-date, to build the master chronology as well as to determine tree age structure of forest on the basis of the technique developed by (Vasileva and Panayotov, 2016).

\section{Sample preparation and data analysis}

The collected tree cores were preceded for laboratory analysis at the Nepal Academy of Science and Technology (NAST). The dried samples were mounted on the wooden frame followed by sanding and polishing manually until the ring boundaries were clearly visible under microscope. Each ring were counted and dated to the calendar year (Stokes and Smiley, 1968) with the known date of outer ring formation. With the help of LINTAB Measurement System attached to a PC having TASP-win Software, the ring-width of each series were then measured. Crossdating was done in TSAP by using alignment plotting technique and crossdating statistics (Rinn, 2003). Accuracy of measurement and crossdating was further examined using quality control program COFECHA (Holmes, 1983). Series with several breakages or having individualistic growth properties were discarded from further analysis. Detrending of raw tree-ring series was carried out in ARSTAN as well as dplR (Bunn, 2008). A 40 year cubic smoothing spline was fitted for standardization and removal of age related growth trend and finally a standard ring-width chronology was developed. Autocorrelation present in the standard chronology was removed with the help of autoregressive (AR) modelling to develop residual chronology.

\section{Climatic data analysis}

The observed climate data is necessary to examine the response of tree growth (ring-width chronology) with the climate, which is the basis for growth response analysis. As Kyangjin is the nearest station located from the site but it has data of very short duration of time expanding from AD 1987 to 2015 with many missing values. Therefore, the data of Kyangjin climate data was of no use for this study. Other nearest meteorological station was Dhunche station. The precipitation data of this station ranged from $A D$ 1971 to 2015 whereas, the temperature data ranged from AD 1996 to 2015. There were also missing 
data in both temperature and precipitation. So, due to relatively shorter period of time, online climate datasets, i.e. climate research unit time series data sets (CRU TS3. 24) from the nearest grids region longitude $=85.00$ to $85.50^{\circ}$, latitude $=28.00$ to $28.50^{\circ}$ were downloaded using KNMI climate explorer (Trouet and Oldenborgh, 2013; http : //climexp. knmi. nl/). The CRU TS 3.24 has climate data from AD 1901 to 2016. As it is always good to use instrumental data, the climate data of Dhunche Station was collected. The data of this Station has relatively longer period as compared to that of Kyangjin Station, and so it has been also used by different researchers for their study in Langtang National Park. The climatic data of this Station showed strong association with the average climate data of the grids $(\mathrm{n}=152, \mathrm{p}<0.01)$. The $\mathrm{CRU}$ grid climate data was used for response analysis. The climate record of this Station showed that June, July, August and September were the hotter months whereas November, December, January and February being the cooler months during the period of 1901-2016 AD (Figure 2). Similarly, higher precipitations were experienced in April, May, June, July and August whereas the months of September, October, November and December had lesser precipitation (Figure 2).

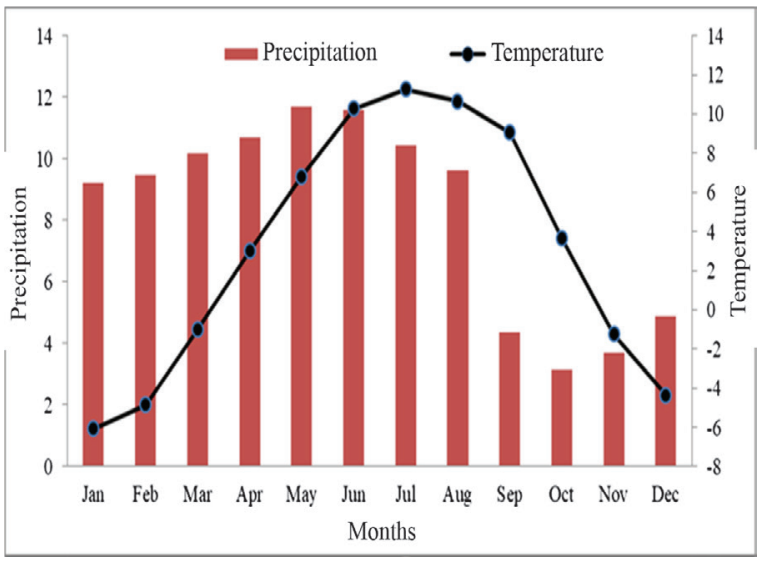

Figure 2 : Mean Monthly Rainfall and Temperature (CRU TS 3. 24) of study region of Himalayan region

\section{Results and discussion \\ Fire Characteristics (Analysis of Cross- sections and Cores) in study area}

Altogether, 8 cross-sections from three different trees species (4 cross-sections from Abies spectabilis, 2 from Juniper sp. and 2 from Pinus wallichiana) were collected from the field. The fire history of $A$. spectabilis was reconstructed based on the 4 cross-sections and 20 cores from 10 different visible trees with fire scars. The fire history of the other two species was not remodeled due to a fewer samples to accurately date the fire occurrence. After sanding and polishing, the cross-sections were analyzed, but no visible fire scars were seen. However, 12 cores of A. spectabilis showed that three fires have occurred and burned the forest area simultaneously during the periods of 1917-1918, 1969-1970 and 2009-2010 respectively. Example of potential fire marks visible in the tree cores of $A$. spectabilis are shown in Figure 3 . Those fire occurrence events found from the tree core analysis were then cross-matched with the perception given by the local people and with the calendar year together with those years where massive fire had occurred at study area based on literatures (Kharel, 1993; Khadka, 2009; Mitchell, 2009; Malakar, 2012). These fire years experienced during hot climate and less rainfall compared to the other non-fire years. However due to lack of references of fire history in the region, it was difficult to identify all the fire scars in all cores and date according to the calendar year. Tree-ring based fire reconstruction is noble study for Himalayan region, as there is no such study from the region. However, previous studies from India and Bhutan have shown the potential and suitability of Pinus roxburghii (Brown et al., 2011) and P. wallichiana in the forest fire history reconstruction from the Himalayan region. As these species are also widely distributed in the Himalayan region, there is a possibility to extend forest fire history reconstruction in the middle to high mountain regions of Nepal.

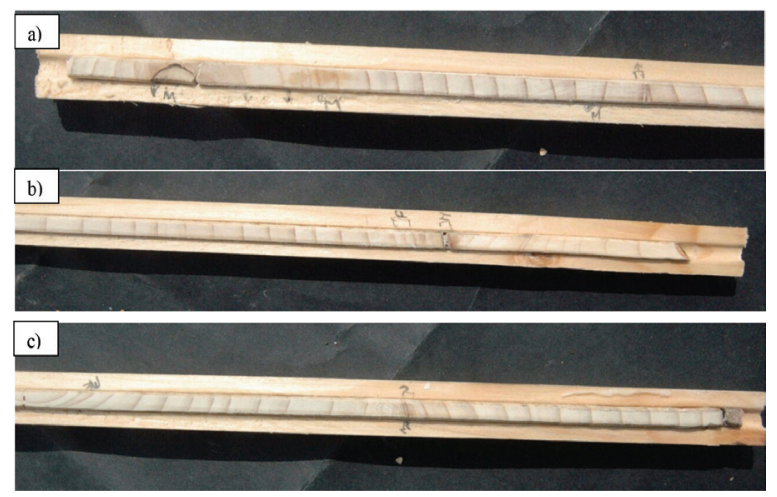

Figure 3 : Pictures (a, $b$ and $c$ ), showing the potential fire scars in the tree core samples of Abies spectabilis 


\section{Tree ring-width chronology from Langtang}

A 199-year long residual ring-width chronology extending from 1818 to 2016 AD was prepared which showed growth fluctuations over time (Figure 4). There was a long positive growth trend since 1850 s to nearly 1950 s after which there is continuous decline in the growth of $A$. spectabilis.

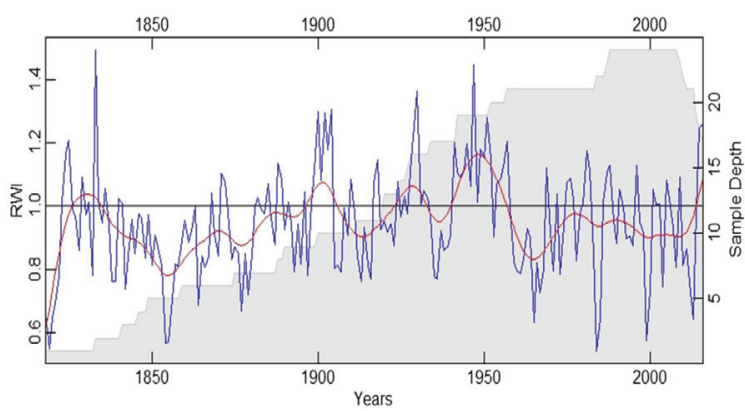

Figure 4 : The residual ring-width chronology of Abies spectabilis from the Langtang region of Nepal Himalaya with red colored curve representing 40 years spline-smoothing curve

The average annual radial growth of $A$. spectabilis was $1.26 \mathrm{~mm} /$ year. The value of mean sensitivity was 0 . 32 with the standard deviation 0.295 . The correlation within trees, between trees and for all series was 0 . $505,0.254$ and 0.263, respectively. The SNR was 6. 1 and the EPS was also above the commonly used threshold for common period (Table 1).

The chronology statistics observed in this study are similar to those reported for the same species from Langtang and other regions (Chhetri and Thapa, 2010; Gaire et al., 2011, 2014, 2017; Shrestha et al., 2017). The growth trends observed in this study were found to be similar with those of the previous studies (Chhetri and Thapa, 2010; Dawadi et al., 2013; Gaire et al., 2011, 2014; 2017, Shrestha et al., 2017). Chhetri and Thapa (2010) did not observe any persistent trend in the growth of the species. Gaire et al. (2011) also did not find any persistent growth trend during the past 220 years in the A. spectabilis chronology growing at treeline ecotone of the LNP. On the contrary, Shrestha et al. (2017) found increasing and decreasing growth trend in the A. spectabilis chronology along the elevation gradient in the Langtang region. Similarly, Dawadi et al. (2013) also observed fluctuation in the growth of $B$. utilis over the past 400 years in the Langtang region. Similarly, Thapa et al. (2017) also reported increasing or decreasing growth trend in different chronologies from Nepal Himalaya. The differences between the growth trends in the present study and the previous studies could be due to the differences in the species, site conditions as well as methods used to detrend the raw tree-ring series, and the type of chronologies.

Table 1 : The chronology statistics of Abies spectabilis ring-width chronology from LNP, Nepal Himalaya

\begin{tabular}{|l|c|}
\hline Statistics & $\begin{array}{c}\text { Residual Chro- } \\
\text { nology }\end{array}$ \\
\hline $\begin{array}{l}\text { Average annual radial } \\
\text { growth }\end{array}$ & 1.26 \\
\hline Mean segment length & 107 \\
\hline $25^{\text {th }}$ quantile & 72 \\
\hline $75^{\text {th }}$ quantile & 150 \\
\hline Time span & $\begin{array}{c}(1818-2016 \\
\text { AD) }\end{array}$ \\
\hline Cores (trees) & $24(19)$ \\
\hline Mean sensitivity & 0.320 \\
\hline Standard deviation & 0.295 \\
\hline *Ac1 & 0.036 \\
\hline Common interval & 52 \\
\hline r-bar (-) (all series) & 0.263 \\
\hline r-bar (-) (within trees) & 0.505 \\
\hline r-bar (-) (between trees) & 0.254 \\
\hline Effective chronology signal & 0.338 \\
\hline $\begin{array}{l}\text { Signal-to-Noise Ratio } \\
\text { (SNR) }\end{array}$ & 6.080 \\
\hline $\begin{array}{l}\text { Expressed Population Sig- } \\
\text { nal (EPS) }\end{array}$ & 0.859 \\
\hline
\end{tabular}

\section{Climate growth relationship of $A$. spectabilis}

After examining the chronology characteristics of A. spectabilis, it was found that it has dendroclimatic potential and suitable for assessing the growth-climate response analysis (Fritts, 1976 and Speer, 2010). The response analysis carried out between the ring-width chronology and climate revealed a significant positive relationship with the temperatures of January and June of the current growth year (Figure 5). Precipitation of June, August, September and October showed significant negative relationship with the ring-width 
chronology whereas the precipitation of March showed positive relationship (Figure 6).

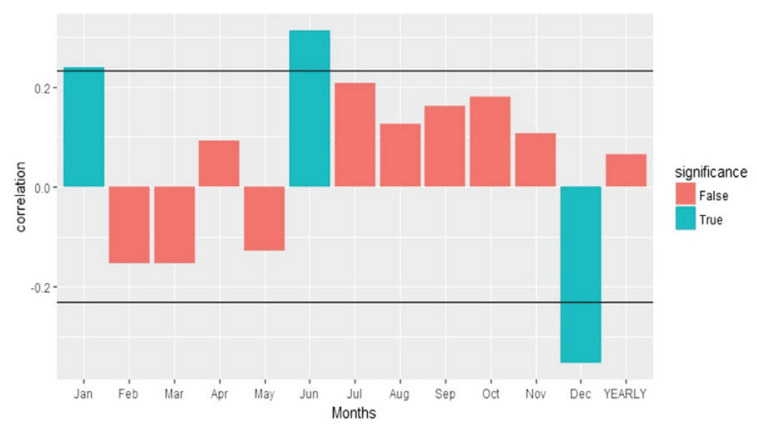

Figure 5 : Response between $A$. spectabilis chronology and climate (temperature) of study area at $(p>0.05)$

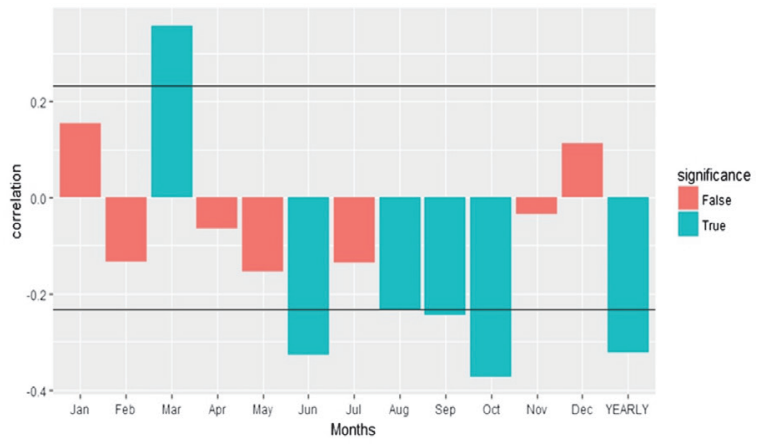

Figure 6 : Response between $A$. spectabilis chronology and climate (precipitation) of the study area $(p>0.05)$

The seasonal correlation showed that there was significant negative response between monsoon and autumn season precipitation with tree ring chronology (Figure 7). On the contrary, there was a significant positive response between the tree ring chronology and monsoon season temperature (Figure 8).

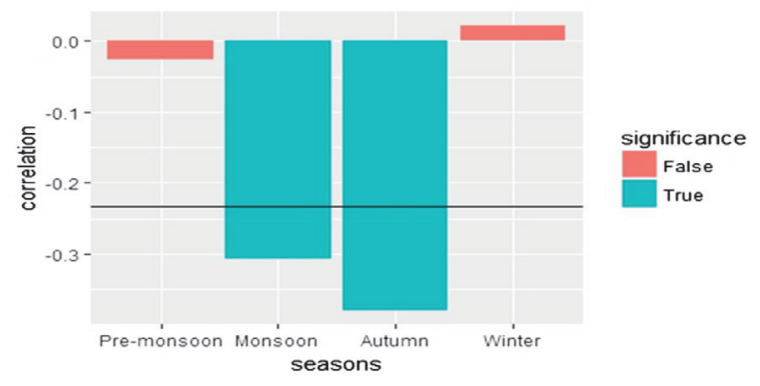

Figure 7 : Seasonal correlation result between tree-ring data of $A$. spectabilis and climate (precipitation) of the study area $(p>0.05)$

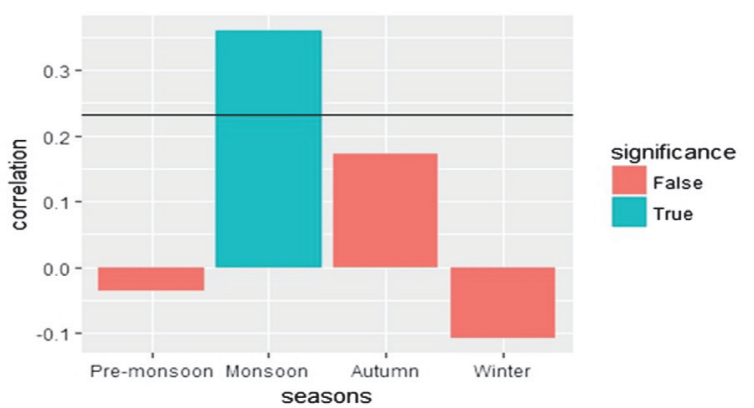

Figure 8 : Seasonal correlation result between tree-ring data of $A$. spectabilis and climate (temperature) of the study area $(p>0.05)$

The overall growth climate relationship result revealed that the growth of $A$. spectabilis in the study area was mainly limited due to low temperature during the growing season and moisture availability during the beginning of the growing season, especially during March. June is the peak growing season for tree growth in the study area; therefore, higher temperature during this month would be beneficial for the growth of the trees there. As the study area received less precipitation during the pre-monsoon season, the moisture availability during this season, which is also the growth start period, is very important for tree growth. The rainfall during the monsoon and autumn season is negatively associated with the growth. This could be due to indirect effect of temperature. Our study area lies in humid region with summer monsoon rainfall mainly contributing for annual rainfall and area receiving sufficient water for tree growth (more than $2000 \mathrm{~mm}$ annual rainfall). High rainfall in monsoon means, higher cloud coverage in the area, which blocks the incoming solar radiations and ultimately lowering the temperature. High rainfall with high cloud cover in the area can lead to temperature decrease. This could shorten the growth period or affects the lignifications of the cells of $A$. spectabilis, ultimately negatively affecting the growth of the species. The decrease in temperature negatively affects the growth as we found a positive relationship between the growth and temperature during monsoon season.

The relationship between A. spectabilis growth and the climate variables were relatively weaker and more diverse in comparison to the findings from the previous literatures. However, the study done on this species at different parts of the Himalayan region were receptive with the 
temperatures of different seasons like winter (Suzuki, 1990; Cook et al., 2003; Bräuning, 2004; Lv and Zhang, 2012; Chhetri and Cairns, 2016), spring (Sano et al., 2005; Gaire et al., 2011; Kharal et al., 2016; Tiwari et al., 2016) and summer (Cook et al., 2003; Lv and Zhang, 2012; Gaire et al., 2017) but the literatures showed, a strong negative relationship with temperature and a positive relationship with precipitation during the pre-monsoon months as the dominant climatic signals for this species in the Nepal Himalaya. The results of this study showed slightly different responses to climate than those observed in the same species from the region (Gaire, 2008; Chhetri and Thapa, 2010; Gaire et al., 2011; Shrestha et al., 2017). Some differences in the response with previous studies could be due to the variations in the methods used for chronology development and differences in the climate data used for response analysis. Similarly, some differences in the response with the previous studies could arise due to site condition too. The bases of the trunks of almost all the sampled trees in the present study were found to be affected by the fire with the visible fire scars which may affect the physiological activities of the trees and thus, to some extent, influence the climate signal of the growth.

\section{Conclusion}

This research was carried out in the Langtang National Park in Nepal Himalaya to know the potentiality of $A$. spectabilis to reconstruct the fire history in the region. The fire history reconstructed from the tree-ring study $(1917-1918,1969-1970$ and 2009-2010) matched well with the local peoples' reporting. As the Abies trees affected by several fire events in the past are still standing alive in the study area, it could be concluded that A. spectabilis is resistant to minor fire events and suitable for fire history study. By collecting the samples from frequent fire-affected areas and analysis of the samples with more sophisticated instruments can give the fire frequency and intensity result more precisely. Not only that, this kind of study can be replicated in the other areas by incorporating other fire sensitive species like P. roxburghii, $P$. wallichiana, and Juniper species. The climatic response of $A$. spectabilis growth from the historic fire affected study area was diverse and weaker in comparison to the findings from the previous literatures indicating some effects of fires on modulating climate-growth response.

\section{Acknowledgements}

We acknowledge the Department of Environment Science and Golden Gate International College for the financial support to this work. The authors are also thankful to the National Academy of Science and Technology (NAST) for facilitating the use of its tree-ring laboratory. We would also like to express our gratitude to the Department of National Parks and Wildlife Conservation and Langtang National Park Office for their permission to carry out this study. Finally, we are obliged to Mr. Amar Bahadur Basnet for assisting us during sample collection and Mr. Sugam Aryal for sample preparation and analysis.

\section{References}

Beaty, R. M., and Taylor, A. H. 2008. Fire history and the structure and dynamics of a mixed conifer forest landscape in the northern Sierra Nevada, Lake Tahoe Basin, California, USA. Forest Ecology and Management 255 : 707-719.

Bradstock, R. A. 2010. A biogeographic model of fire regimes in Australia : current and future implications. Global Ecology and Biogeography 19 (2) : 145-158.

Bräuning, A. 2004. Tree-Ring Studies in The Dolpo-Himalaya (Western Nepal). Tree Rings in Archaeology. Umwelt, Reihe : Climatology and Ecology.

Brown, P. M., Bhattacharyya, A. and Shah, S. K. 2011. Potential for Developing Fire Histories in Chir Pine (Pinus roxburghii) Forests in the Himalayan Foothills. TreeRing Research 67 (1) : 57-62.

Bunn, A. G. 2008. A dendrochronology program library in R (dplR). Dendrochronologia 26 (2) : 115-124.

Chhetri, P. K. and Cairns, D. M. (2016). Dendroclimatic response of Abies spectabilis at treeline ecotone of Barun Valley, Eastern Nepal Himalaya. Journal of Forestry Research 27 (5) : 1163-1170. 
Chhetri, P. K. and Thapa, S. 2010. Tree ring and climate change in Langtang National Park : Central Nepal. Our Nature 8 : 139-143.

Christopoulou, A., Fulé, P. Z., Andriopoulos, P., Sarris, D. and Arianoutsou, M. 2013. Dendrochronology-based fire history of Pinus nigra forests in Mount Taygetos, Southern Greece. Forest Ecology and Management 293 : 132-139.

Cohen, D., Dellinger, B., Klein, R. and Buchanan, B. 2007. Patterns in lightning-caused fires at Great Smoky Mountains National Park. Fire Ecology 3 (2) : 68-82.

Cook, E. R., Krusic, P. J. and Jones, P. D. 2003. Dendroclimatic signals in long tree-ring chronologies from the Himalayas of Nepal. International Journal of Climatology 23 : 707-732.

Dawadi, B., Liang, E., Tian, L., Devkota, L. P., \& Yao, T. 2013. Pre-monsoon precipitation signal in tree rings of timberline Betula utilis in the central Himalayas. Quaternary International $283: 72-77$.

Dimitrakopoulos, A. P., Vlahou, M., Anagnostopoulou, C. G. and Mitsopoulos, I. D. 2011. Impact of drought on wildland fires in Greece : Implications of climatic change? Climate Change 109 : 331-347.

Fritts, H. C. (1976). Tree Rings and Climate. London : Academic Press, London, 567 pp.

Fowler, C. and Konopik, E. 2007. The history of fire in the southern United State. Human Ecology Review 14 (2) : 165-176.

Gaire, N. P. 2008. Ecology and dendroclimatology of treeline forest in Langtang National Park, Nepal Himalaya. A MSc. dissertation submitted to Central Department of Environmental Science, Tribhuvan University, Kathmandu, Nepal.

Gaire, N. P., Bhuju, D. R., \& Koirala, M. (2013). Dendrochronological studies in Nepal : Current status and future prospects. FUUAST J. Bio., 3 (1) : 1-9.
Gaire, N. P., Bhuju, D. R., Koirala, M., Shah, S. K., Carrer, M. and Timilsena, R. 2017. Tree-ring based spring precipitation reconstruction in western Nepal Himalaya since AD 1840. Dendrochronologia 42 : $21-30$.

Gaire, N. P., Dhakal, Y. R., Lekhak, H. C., Bhuju, D. R. and Shah, S. K. 2011. Dynamics of Abies spectabilis in relation to climate change at the treeline ecotone in Langtang National Park. Nepal Journal of Science and Technology 12 : 220-229.

Gaire, N. P., Koirala, M., Bhuju, D. R. and Borgaonkar, H. P. 2014. Treeline dynamics with climate change at the central Nepal Himalaya. Climate of the Past 10 (4) : 1277-1290. doi : 10. 5194/cp-10-12772014.

Gaire, N. P., Koirala, M., Bhuju, D. R. and Carrer, M. 2016. Site and species-specific treeline responses to climatic variability in eastern Nepal Himalaya. Dendrochronologia 41 : 44-56, http : //dx. doi. org/10. 1016/j. dendro. 2016. 03. 001.

Gyeltshen, C. and Tenzin, K. 2018. Fire Disturbance in Blue Pine Forests of Bhutan : A Technical Note. Ugyen Wanghuck Institute for Conservation and Environmental Research, Bumthang, Bhutan.

GoN/MFSC. 2010. Forest Fire Management Strategy 2010. Kathmandu, Nepal : Ministry of Forests and Soil Conservation, Government of Nepal.

Heon, J., Arseneault, D. and Parisien, M. A. 2014. Resistance of the boreal forest to high burn rates. Proceedings of the National Academy of Sciences of the USA. 111 (38) : 13888-93.

Holmes, R. L. 1983. Cumputer-assisted quality control in tree-ring datinf and measurement. Tree-ring bulletin $43: 69-78$.

Hurteau, M. D., Bradford, J. B., Fulé, P. Z., Taylor, A. H. and Martin, K. L. 2014. Climate change, fire management and ecological 
services in the South-western US. Forest Ecology and Management 327 : 280-289.

Khadka, N. S. 2009. BBC Nepali Service. http : //news. bbc. co. uk/2/hi/science/ nature/7968745. stm

Kharal, D. K., Thapa, U. K., George, S. S., Meilby, H., Rayamajhi, S. and Bhuju, D. R. 2016. Tree-climate relations along an elevational transect in Manang Valley, central Nepal. Dendrochronologia 41 : 57-64.

Kharel, F. R. 1993. Park-People Conflict in Langtang National Park, Nepal/ A thesis submitted in partial fulfillmentof the requirements for the degree of Master of Parks and Recreation Management at Lincoln University, Canterbury, New Zealand.

Liu, L. X. and Zhang, Q. B. 2012. Asynchronous recruitment history of Abies spectabilis along an altitudinal gradient in the Mt. Everest region. Journal of Plant Ecology 5 (2) : 147-156.

Malakar, N. K. 2012. http : //www. nabinkm. $\operatorname{com} / 2012 / 12 /$ wild-fire-in-langtangnational-park. html

Mitchell, J. 2009. Fotolibra. http : //www. fotolibra. com/gallery/779263/forest-fireslangtang-himalaya-nepal/

Moreira, F., Viedma, O., Arianoutsou, M., Curt, T., Rigolot, E. and Barbati, A. 2011. Landscape-wildfire interactions in Southern Europe : implications for landscape management. Journalof Environmental Management 92 : 23892402.

Pausas, J. G. and Fernández-Muñoz, S. 2012. Fire regime changes in the Western Mediterranean Basin : from fuel-limited to drought-driven fire regime. Climate Change 110 (1-2) : 215-26.
Rinn, F. (2003). TSAP-Win : time series analysis and presentation for dendrochronology and related applications. Version 0. 55 User reference. Heidelberg, Germany : RINNTECH.

Pausas, J. G. and Keeley, J. E. 2009. A burning story : the role of fire in the history of life. BioScience 59 (7) : 593-601.

Rollins, M. G., Morgan, P. and Swetnam, T. 2002. Landscape-scale controls over $20^{\text {th }}$ century fire occurrence in two large rocky mountain wilderness areas (USA). Landscape Ecology 17 (6) : 539-57.

Sano, M., Furuta, F., Kobayashi, O. and Sweda, T. 2005. Temperature variations since the mid-18th century for western Nepal, as reconstructed from tree-ring width and density of Abies spectabilis. Dendrochronologia 23 : 83-92.

Sharma, S. P. 1996. Forest fire in Nepal. International Forest Fire News 15 : 36-39.

Shrestha, K. B., Chhetri, P. K., and Bista, R. 2017. Growth response of Abies spectabilis to climate variations along an elevational gradient in Langtang National Park in the central Himalaya Nepal. Journal of Forestry Research 22 (5) : 274-281. https : //doi. org/10. 1080/13416979. 2017. 1351508 .

Skinner, C. N., Burk, J. H., Barbour, M. G., Franco-Vizcaíno, E. and Stephens, S. L. 2008. Influences of climate on fire regimes in montane forests of north-western Mexico. Journal of Biogeography 35 : 1436-1451.

Speer, J. H. 2010. Fundamentals of Tree-Ring Research. The University of Arizona Press, Tucson.

Suzuki, E. 1990. Dendrochronology in coniferous forests around Lake Rara, West Nepal. The Botanical Magazine 103 : 297-312,Tokyo. 
Thapa, U. K., George, S. S., Kharal, D. K., \& Gaire, N. P. (2017). Tree growth across the Nepal Himalaya during the last four centuries. Progress in Physical Geography, 41 (4) : 030913331771424.

Tiwari, A., Fan, Z. X., Jump, A. S., Li, S. F. and Zhou, Z. K. 2016. Gradual expansion of moisture sensitive Abies spectabilis forest in the Trans-Himalayan zone of central Nepal associated with climate change. Dendrochronologia 41 : 34-43.

Trouet, V. and Oldenborgh, G. J. V. 2013. KNMI climate explorer : a web based research tool for high-resolution paleoclimatology. Tree-Ring Research 69 (1) : 3-13.
Vasileva, P. and Panayotov, M. 2016. Dating fire events in Pinus heldreichii forests by analysis of tree ring cores. Dendrochronologia 38 : 98-102.

Xiaochun, W. and Ying, J. 2009. Review of advances in dendropyrochronology. Journal of Plant Ecology 33 (3) : 587-597 (in Chinese Version). 